\title{
Anomalous ovarian artery vascularisation of a large uterine fibroid: successful embolisation
}

\author{
Pascale Riu, ${ }^{1}$ Cristina Vallone, ${ }^{2}$ Giuliano Rigon, ${ }^{2}$ Fabrizio Signore ${ }^{2}$
}

${ }^{1}$ Department of Obstetrics and Gynaecology, Hospital San Camillo-Forlanini, Rome, Italy IInterventional Radiology Service, Hospital San CamilloForlanini, Rome, Italy

\section{Correspondence to}

Dr Fabrizio Signore,

fsignore@scamilloforlanini.rm.it

\section{DESCRIPTION}

Successful embolisation of an abnormal ovarian artery (OAE) feeding a fundal uterine fibroid is rarely reported.

A 50-year-old woman presented with vaginal bleeding and anaemia. Ultrasound and MRI showed a single large fundal subserosal fibroid. CA 19.9, CEA, CA 125 and LDH were normal. Aortic angiography showed an exclusive supply to a leiomyoma from a hypertrophic right ovarian artery. No feeding from the uterine artery was observed. A microcatheter was inserted to the mid-third of the ovarian artery. Tris-acryl gelatin microspheres, 700$900 \mu \mathrm{m}$ (embosphere microsphere) were injected until near-stasis was achieved. A bilateral uterine angiogram confirmed no additional vascular supply to the leiomyoma (figure 1). The fibroid volume decreased by $30 \%$, according to MRI over 3 months. Fibroids usually derive their blood supply from the uterine artery, but vascularisation from the ovarian artery is possible. ${ }^{1}$ Blood supply to uterine fibroids can also originate from an aortoiliac haemorrhoidal artery or from distal branches of the
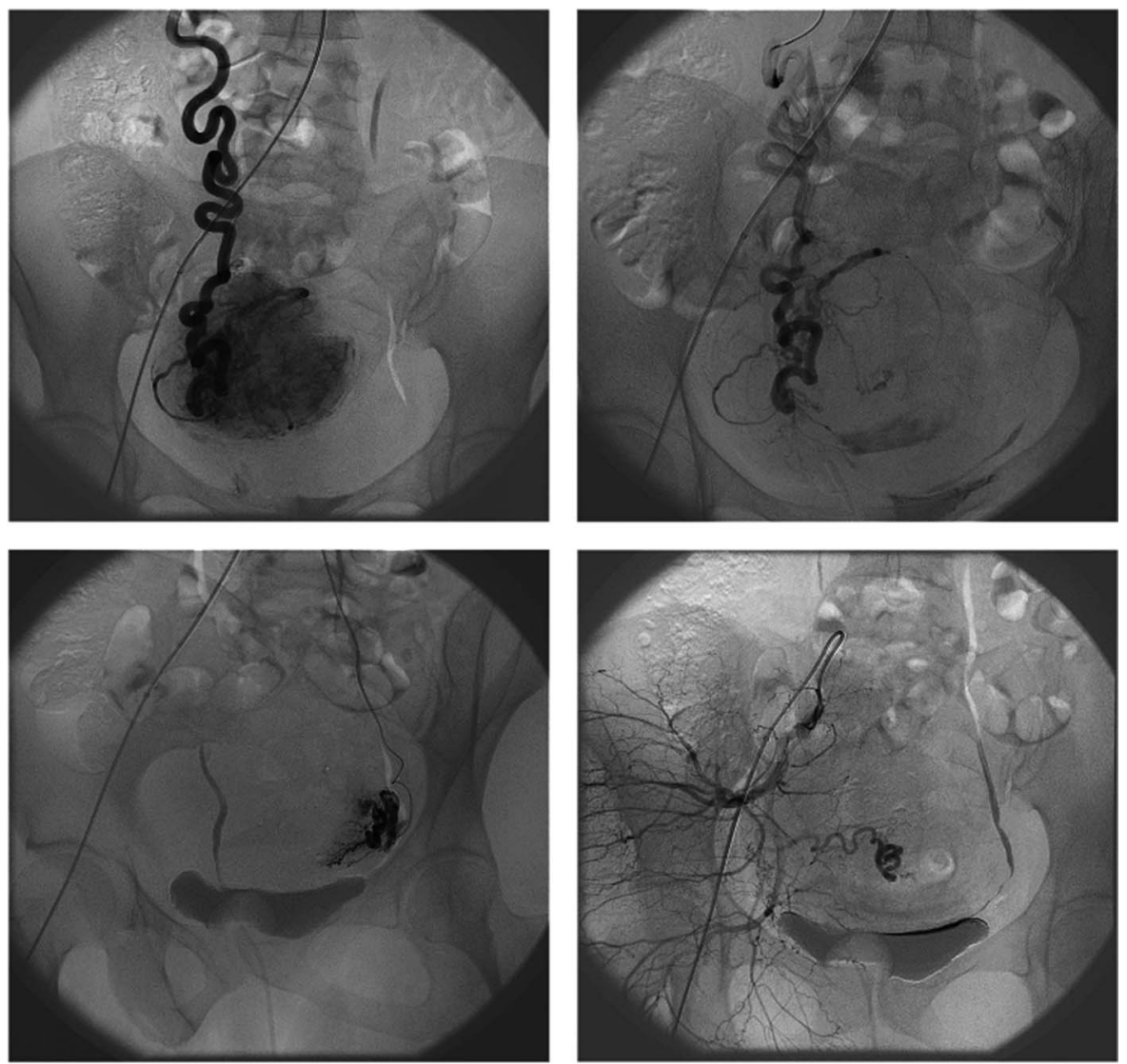

Figure 1 Panel 1: fibroid supply from the ovarian artery; Panel 2: uterine bleeding; Panel 3: no left uterine artery supply; Panel 4: no right uterine artery supply. inferior mesenteric. Uterine artery embolisation (UAE) is a widely accepted treatment for uterine fibroids and ovarian function seems to be unaffected by the procedure. ${ }^{2}$ Compared with UAE alone, the addition of OAE to UAE neither appear to precipitate the onset of menopause nor increase menopausal symptom severity. ${ }^{3}$ The predominant flow to the peri-fibroid plexus can possibly lead to a targeted embolisation, avoiding damage to the ovary using larger particles (700-900 embospheres).

\section{Learning points}

Large fundal uterine fibroids can have an exclusive ovarian artery supply.

- An isolated ovarian artery embolisation (OAE) can be successful with no need to repeat procedures or necessity of an associated uterine artery embolisation.

- In our case, ovarian function was preserved after exclusive OAE.
To cite: Riu P, Vallone $C_{1}$ Rigon $\mathrm{G}$, et al. BMJ Case Reports Published online: [please include Day Month Year] doi:10.1136/bcr-2012008106 
Competing interests None.

Patient consent Obtained.

Provenance and peer review Not commissioned; externally peer reviewed.

\section{REFERENCES}

1 Razavi MK, Wolanske KA, Hwang GL, et al. Angiographic classification of ovarian artery-to-uterine artery anastomoses: initial observations in uterine fibroid embolization. Radiology 2002;224:707-12.
2 Kim HS, Paxton BE, Lee JM. Long-term efficacy and safety of uterine artery embolization in young patients with and without uteroovarian anastomoses. J Vasc Interv Radiol 2008:19:195-200.

3 Scheurig-Muenkler C, Poellinger A, Wagner $\mathrm{M}$, et al. Ovarian artery embolization in patients with collateral supply to symptomatic uterine leiomyomata. Cardiovasc Intervent Radiol 2011;34:1199-207.

Copyright 2013 BMJ Publishing Group. All rights reserved. For permission to reuse any of this content visit http://group.bmj.com/group/rights-licensing/permissions.

BMJ Case Report Fellows may re-use this article for personal use and teaching without any further permission.

Become a Fellow of BMJ Case Reports today and you can

- Submit as many cases as you like

- Enjoy fast sympathetic peer review and rapid publication of accepted articles

- Access all the published articles

- Re-use any of the published material for personal use and teaching without further permission

For information on Institutional Fellowships contact consortiasales@bmjgroup.com

Visit casereports.bmj.com for more articles like this and to become a Fellow 